Jurnal Informatika dan Rekayasa Perangkat Lunak (JATIKA)
Vol. 1, No.1 2020, Page 36 42

\title{
PEMANFAATAN AUGMENTED REALITY DALAM APLIKASI MAGIC BOOK PENGENALAN PROFESI UNTUK PENDIDIKAN ANAK USIA DINI
}

\author{
Dian Nurmanto ${ }^{1}$, RakhmatDedi $\mathbf{G}^{2}$ \\ S1 Informatika, UniversitasTeknokrat Indonesia ${ }^{1}$ \\ S1 Informatika, UniversitasTeknokrat Indonesia ${ }^{2}$ \\ nurd859@gmail.com¹, rakhmatdedig@teknokrat.ac.id ${ }^{2}$
}

Received: (Mei 2020)Accepted: (Mei 2020) Published: (Juni 2020)

\begin{abstract}
The introduction of various professions is one of the material contained in PAUD, which is expected to provide knowledge of the function of the profession's role and can foster ideals in students and not underestimate a profession. In the process of delivering material requires learning media and media that are often used are books that have 2-dimensional images. Learning media is needed that can increase student interest in learning so that the absorption of the material becomes more maximal. The application of Augmented Reality technology to learning media can increase students' interest and interest in learning so as to optimize the reception of material for students. Learning media for introducing professions based on Augmented Reality technology in the form of a magic book application are operated on Andoroid smartphone devices, by utilizing the camera contained in the device used for tracking markers that have been determined and produce $3 D$ objects on the screen accompanied by a sound containing an explanation of the profession that appears. The choice of using an Android smartphone is based on the large number of Android device users in Indonesia. Testing the application of Augmented Reality technology functionally using the blackbox method, which is carried out in various kinds of Android smartphones in various Android versions and brands. Based on the test results obtained a score of $91.67 \%$ which can be concluded that the application is made in the category "Very Eligible".
\end{abstract}

Keywords: Android, Augmented Reality, learning media, profesional introduction, PAUD.

\begin{abstract}
Abstrak
Pengenalan berbagai macam profesi merupakan salah satumateri yang terdapat pada PAUD, yang diharapkan dapat memberikan pengetahuan akan fungsi dari peran profesi tersebut dan dapat menumbuhkan cita-cita pada siswa serta tidak memandang remeh dari suatu profesi. Dalam proses penyampaian materi membutuhkan media pembelajaran dan media yang sering digunakan adalah buku yang terdapat gambar 2 dimensi. Diperlukan media pembelajaran yang dapat meningkatkan minat belajar siswa agar penyerapan materi menjad ilebih maksimal. Penerapan teknologi Augmented Reality pada media pembelajaran dapat meningkatkan minat dan kertarikan siswa untuk belajar sehingga bisa mengoptimalkan penerimaan materi bagi siswa. Media pembelajaran pengenalan profesi berbasis teknologi Augmented Reality dalam bentuk aplikasi magic book dioperasikan pada perangkat smartphone Andoroid, dengan memanfaatkan kamera yang terdapat pada device digunakan untuk mentracking marker yang sudah ditentukan dan menghasilkan objek 3D pada layar yang disertai suara berisi penjelasan mengenai profesi yang muncul. Pemilihan penggunaan smartphone Android didasarkan pengguna perangkat Android di Indonesia yang sangat besar. Pengujian penerapan teknologi Augmented Reality secara fungsional menggunakan metode blackbox, yang dilakukan diberbagai macam smartphone android berbagai versi Android dan merk. Berdasarkan hasil pengujian didapatkan skor 91,67\% yang dapat disimpulkan aplikasi yang dibuat masuk kategori "Sangat Layak".
\end{abstract}

Kata Kunci: Android, Augmented Reality, media pembelajaran, pengenalan profesi,PAUD. 
To cite this article

Dian Nurmanto, Rakhmat Dedi G. (2020). Pemanfaatan Augmented Reality Dalam Aplikasi Magic Book Pengenalan Profesi Untuk Pendidikan Anak Usia Dini, Jurnal Informatika dan Rekayasa Perangkat Lunak, Vol(1), 36-42.

\section{PENDAHULUAN}

Profesi merupakan suatu bidang pekerjaan atau jabatan yang menuntut suatu keahlian atau keterampilan, tanggung jawab serta profesionalisme dari pelakunya. Suatu profesi akan dipilih oleh setiap orang pada saat beranjak dewasa sebagai tujuan dalam hidupnya kedepan. Dalam menekuni profesi tertentu bisa melalaui jalur formal ataupun informal seperti sekolah khusus, pelatihan, seminar atau secara otodidak untuk mendapatkan keahlian atau keterampilan yang dibutuhkan. Pengetahuan mengenai suatu profesi sejak dini terhadap anak akan membantu anak dalam menentukan cita-citanya kelak saat dewasa, membuat anak lebih bersemangat dalam belajar dan membantu anakdalam menempuh jalur Pendidikan yang sesuai. Salah satu materi yang diajarkan pada PAUD adalah pengenalan berbagai macam profesi, yang bertujuan untuk mengetahui fungsi peranan dari profesi tersebut dan para siswa juga bisa menghargai dan tidak memandang rendah profesi orang lain, dan menggali potensi yang ada pada diri mereka sendiri.

Media pembelajaran yang digunakan pada PAUD harus memiliki karakteristik menarik agar siswa lebih antusias dalam mengikuti materi. Pada beberapa PAUD menggunakan media buku sebagai media pembelajaran dalam bentuk visual yaitu gambar 2 dimensi, dimana dalam penggunaan media ini hanya mengaktifkan 1 panca indra saja. Penerapan multimedia dalam media pembelajaran seperti suara, gambar yang berwarna, animasi yang dikemas dalam bentuk informatif dan interaktif akan meningkatkan minat belajar dan antusias siswa untuk belajar (Rahmanto dan Utama, 2018).

Penggunaan teknologi Augmented reality dalam bentuk media pembelajaran dalam penyampaian materi pada PAUD memberikan manfaat positif pada siswa. Pemanfaatan teknologi Augmented Reality dalam media pembelajaran digabungkan dengan jenis media lainya, mampu membuat kegiataan belajar menjadi lebih interaktif (Adrian, 2019) dan menyenangkan karena dapat mengakomodir tiga gaya belajar yang berbeda, dikutip dari LDPride.net, terdapat tiga modalitas dalam gaya belajar yaitu auditori yang merupakan gaya belajar melalui mendengar, gaya belajar kinestetik yang merupakan gaya belajar dengan melakukan sesuatu, menggerakkan badan, dan menyentuh sesuatu dan gaya belajar visual yang merupakan gaya belajar melalui melihat. Hal in dapat meningkat minat dan ketertarikan belajar dari siswa sehingga penyerapan materi akan lebih optimal (Saputra dkk, 2020).

Bentuk aplikasi media pembelajaran Magic Book berbasis teknologi Augmented Reality yang berjalan pada platform Andorid mempermudah pengguna dikarenakan pengguna smartphone berbasis Android di Indonesia sangat besar, berdasarkan hasil penelitian terhadap pengguna android di Indonesia sepanjang 2013 oleh lembaga riset Sharing Vision, pertumbuhan pengguna android mencapai lebih dari 1,5 juta per hari di global, sedangkan berdasarkan Databoks, Kata data Indonesia yang mempublikasikan grafik perkembangan terhadap pengguna smartphone di Indonesia pada tahun 2018 penggunaan smartphone mencapai sekitar 83,5 juta unit.

\section{TELAAH PUSTAKA}

\section{AugmentedReality}

Augmented reality adalah "teknologi yang memungkinkan orang untuk memvisualisasikan dunia maya sebagai bagian dari dunia nyata yang ada di sekitar secara efektif sehingga membuat dunia nyata seakan-akan dapat terhubung dengan dunia maya dan dapat terjadi suatu interaksi”' (Jacobs etal. 2016).

\section{Augmented Reality Book (AR-Book)}

Augmented Reality Book (AR-Book) atau yang dalam Bahasa Indonesia berarti buku berbasis Augmented Reality merupakan "penggabungan antara buku biasa dengan teknologi Augmented Reailty". AR-Book secara garis besar memiliki du komponen utama, yaitu buku yang dilengkapi dengan marker berjeni sQuick Response Code (QRC) pada hampir setiap halamannya, dan yang kedua yaitu peralatan untuk menangkap marker dan menampilkan hasilnya. (Gede et al., 2015) 


\section{METODE PENELITIAN \\ Tahapan Penelitian}

Penelitian merupakan kegiatan yang dilakukan secara terencana, teratur, dan sistematis untuk mencapai tujuan tertentu.

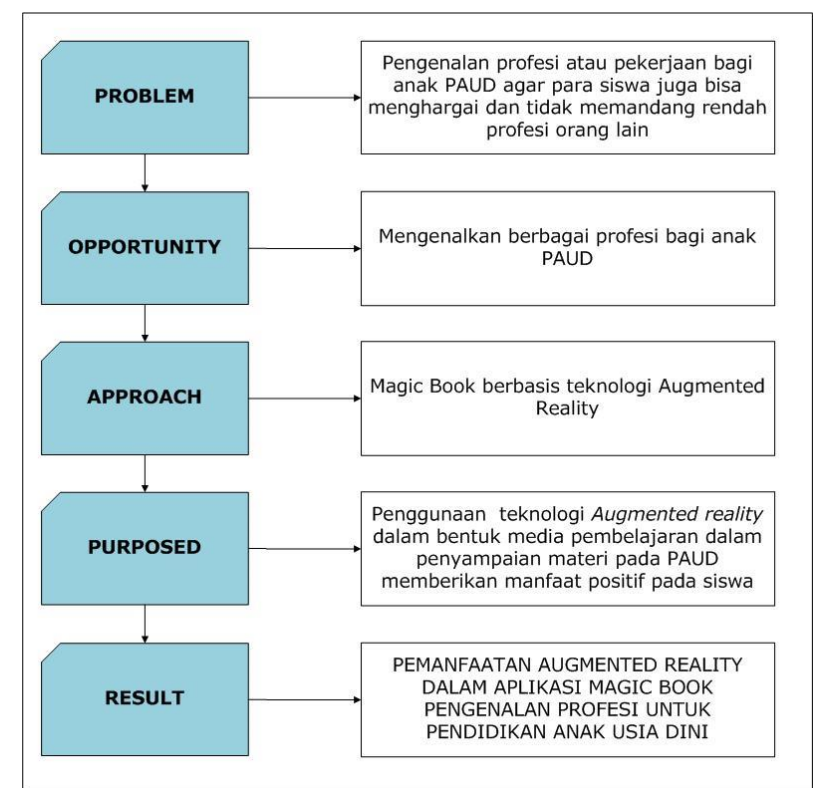

Gambar 1. Tahapan Penelitian

\section{Populasi dan Sampel}

Jumlah sampel/populasi yang terkait dengan penelitian ini berjumlah 20 orang siswa dan 1 orang pengurus sekaligus pengajar pada PAUD Al-Aldi, dan terdapat 9 profesi yang berbeda yaitu : Guru, Polisi, Tentara, Dokter, Perawat, Pilot, Astronot, Pemadam Kebakaran, Koki.

\section{Teknik Pengumpulan Data}

1. Wawancara (Interview)

Metode pengumpulan data yang dilakukan dengan cara menanyakan secara langsung kepada pihakpihak yang berkaitan untuk memperoleh informasi, seperti siswa dan guru. Wawancara dilakukan pada saat awal penelitian, testing dan implementasi produk.

2. Metode Pengamatan (Observasi)

Metode pengumpulan data dengan mengamati dan mempelajari kegiatan dalam kegiatan belajar mengajar pada PAUD Al-Aldi untuk mendapatkan informasi gambaran yang jelas mengenai hal-hal yang dibutuhkan dalam kegiatan penelitian.

3. TinjauanPustaka (Library Research)

Metode pengumpulan data dengan mempelajari kumpulan buku-buku dan penelitian terdahulu yang dilakukan dengan cara membaca literatur-literatur terkait pembuatan aplikasi magic book pengenalan profesi berbasis AR.

\section{Metode Analisis}

Analisis kebutuhan fungsional menghasilkan fungsi-fungsi yang harus tersedia pada layanan system untuk merespon inputan tertentu pada situasi tertentu pada saat digunakan. Kebutuhan fungsional yang harus disediakan pada pembuatan aplikasi magic book pengenalan profesi berbasis augmented reality sebagai berikut :

1. Aplikasi harus dapat mengelola fungsi menu

a. Pengguna bisa melihat scene splash screen. 
b. Pengguna bisa membuka fungsi akses ke menu utama.

c. Pengguna bisa membuka fungsi akses $\mathrm{k}$ emenu augmented reality.

d. Pengguna bisa membuka fungsi akses tampilan objek 3D

e. Pengguna bisa membuka fungsi akses ke menu petunjuk.

f. Pengguna bisa membuka fungsi akses menu informasi.

g. Pengguna bisa membuka fungsi akses menu permainan.

h. Pengguna bisa membuka fungsi akses menu hasilpermainan.

i. Pengguna bisa membuka fungsi akses keluar.

j. Pengguna bisa mengakses tombol kapasitif pada smartphone.

2. Aplikasi harus dapat mengelola fungsi tiap scene simulasi.

a. Pengguna bisa menginterupsisemua scene untukkembalike menu.

b. Pengguna bisa mengakses scene marker Gambar Profesi Guru.

c. Pengguna bisa mengakses scene marker Gambar Profesi Polisi.

d. Pengguna bisa mengakses scene marker Gambar Profesi Tentara.

e. Pengguna bisa mengakses scene marker Gambar Profesi Dokter.

f. Pengguna bisa mengakses scene marker Gambar Profesi Perawat.

g. Pengguna bisa mengakses scene marker Gambar Profesi Astronot.

h. Pengguna bisa mengakses scene marker Gambar Profesi Pilot.

i. Pengguna bisa mengakses scene marker Gambar Profesi Pemadam Kebakaran.

j. Pengguna bisa mengakses scene marker Gambar Profesi Koki.

k. Pengguna bisa mengakses scene objek 3D dengan penjelasan dalam bentuk suara.

1. Pengguna bisa mengakses scene objek 3D dengan pengaturan orientasi objek

$\mathrm{m}$. Pengguna bisa mengakses scene objek 3D dengan pengaturan zoom in/out

n. Pengguna bisa mengakses scene permainanTebak Profesi.

o. Pengguna bisa mengakses scene permainan Puzzle Profesi.

\section{HASIL DAN PEMBAHASAN}

Setelah tahap perancangan selesai maka masuk tahap produksi aset, yaitu menyiapkan asset-aset yang dibutuhkan dalam aplikasi sepert gambar, objek 3D, suara, musik dan marker. Untuk pembuatan gambar dan objek 3D menggunakan aplikasi Blender, suara penjelasan dengan melakukan perekaman, suara efek dan musik mengunduh dari internet dengan lisensi free.

Setelah asset yang dibutuhkan sudah lengkap masuk kedalam tahap program, yaitu menyatukan asset dengan script pemrograman dan mengintegrasikan augmented reality. Aplikasi yang digunakan untuk menggabungkan semua menggunakan Unity 3D, sedangkan untuk SDK augmented reality menggunakan Vuforia.

\section{Penerapan Splash Screen}

Penggabungan tulisan nama aplikasi, gambar latar belakang, 2 gambar profesi berbeda dan bar progress loading splash screen.

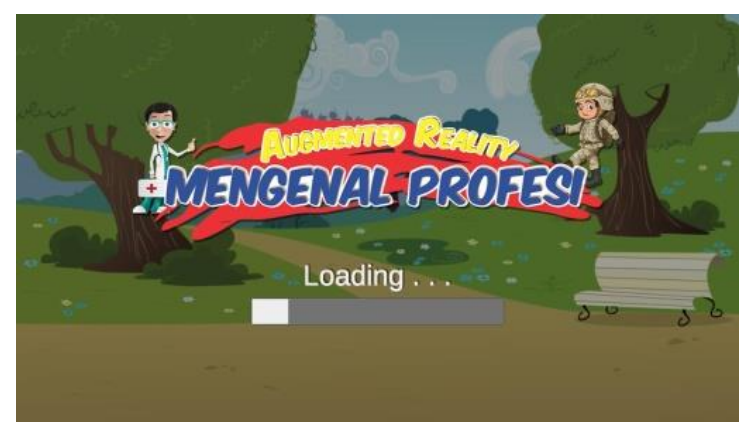

Gambar 2. Splash Screen 


\section{Menampikan Objek 3D Profesi}

Mengarahkan kamera pada marker akan menampilkan objek 3D profesi sesuai dengan marker yang berjumlah dua orang yaitu laki-laki dan perempuan, yang disertakan penjelasan dalam bentuk suara dan bisa dilakukan rotasi kanan/kiri dan juga bisa dilakukan zoom in/out.

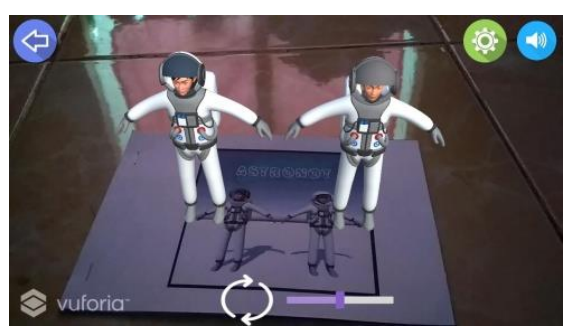

\section{Gambar 3. MenampilkanObjek 3D Profesi}

\section{Menampikan Menu Bermain}

Pemberian menu permainan bisa digunakan untuk melakukan evaluasi terhadap pemahaman siswa setelah mencoba menu pengenalan profesi. Terdapat 2 macam permainan yang diberikan yaitu tebak profesi dan puzzle profesi.

\section{Permainan Tebak Profesi}

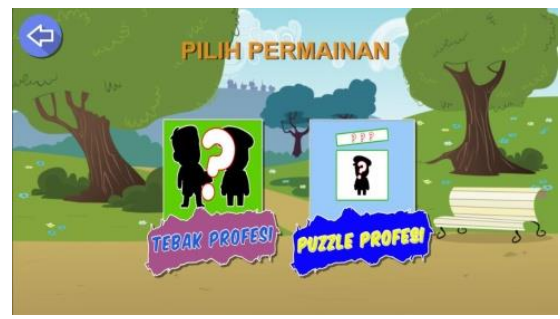

\section{Gambar 4. Menu Bermain}

Permainan Tebak Profesi membutuhkan bantuan guru atau orang tua murid, dikarenakan harus membacakan soal mengenai profesi apa yang sedang ditanyakan, lalu siswa akan memilih salah satu gambar dari 3 gambar yang disediakan, apabila benar akan membuat skor bertambah 10 poin, dalam permainan ini terdapat waktu yang membatasinya.

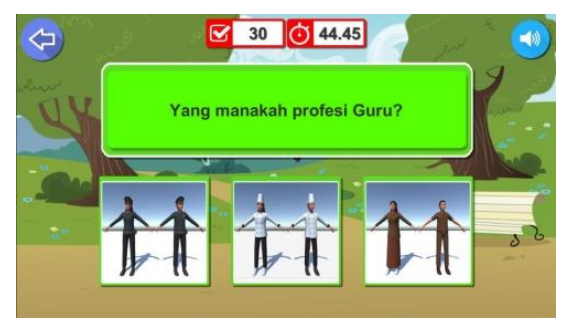

\section{Gambar 5. Permainan Tebak Profesi}

\section{Permainan Puzzle Profesi}

Permainan Puzzle Profesi terdapat 3 macam profesi yang terdiri dari 2 potong puzzle yaitu berupa gambar dan tulisan, dalam permainan ini membutuhkan bantuan guru untuk membacakan puzzle yang berisi tulisan, lalu siswa memilih puzzle tulisan untuk dipasangkan dengan puzzle gambar dengan caradi drag. 


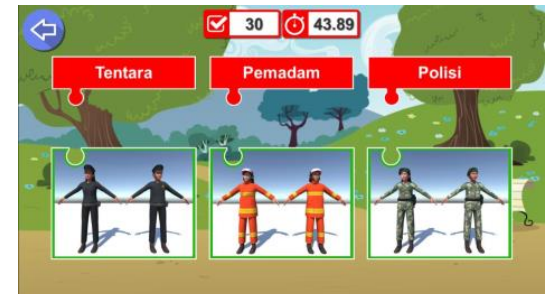

Gambar 6. Permainan Puzzle Profesi

\section{Hasil Permainan}

Setelah waktu yang diberikan untuk bermain habis, maka akan dimunculkan penilaian dalam bentuk poin angka dan dalam bentuk bintang dengan maksimal 3 bintang. Menampilkan hasil dari bermain bisa membuat siswa lebih semangat belajar lagi untuk mendapatkan nilai tertinggi.

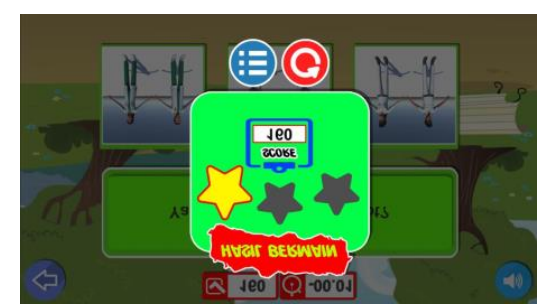

Gambar 7. Hasil Permainan

Bagaimana Pemanfaatan Teknologi Augmented Reality dalam penyampaian materi pengenalan profesi dalam bentuk aplikasi magic book ?

Penggunaan teknologi Augmented Reality dalam sebuah media pembelajaran untuk penyampaian materi pengenalan profesi pada siswa PAUD menjadi lebih interaktif yang dapat meningkatkan minat dan ketertarikan siswa pada profesi tertentu, karena siswa mendapatkan pengalaman belajar dalam tiga gaya belajar, yaitu visual, auditori, dan kinestetik sekaligus. Pemanfaatan Augmented Reality membuat siswa dapat menyentuh dan menggerakan yang kemudian dilanjutkan dengan melihat objek 3D yang menarik yang disertai suara penjelasan yang bisa didengar oleh siswa, pengalaman ini akan membuat pemahaman siswa akan materi akan lebih optimal karena melibatkan lebih banyak panca indra. Ditambah dengan 2 jenis permainan sebagai hiburan bagi siswa dan juga bisa digunakan untuk mengukur tingkat penerimaan materi oleh siswa. Pengukuran mengenai Implementasi aplikasi dilakukan diberbagai macam perangkat yang memiliki OS Android yang berbeda.

Tabel 1. Hasil Perbandingan Perangkat dan Versi OS Andorid

\begin{tabular}{|c|c|c|c|c|}
\hline No & Jenis Device & Jenis Android & $\begin{array}{c}\text { Proses } \\
\text { Instalasi }\end{array}$ & $\begin{array}{c}\text { Proses Running } \\
\text { Aplikasi }\end{array}$ \\
\hline 1. & $\begin{array}{l}\text { Emulator } \\
\text { Android } \\
\text { (Memu) }\end{array}$ & $\begin{array}{c}4.2 .2 \\
(J e l l y \text { Bean })\end{array}$ & $\begin{array}{l}\text { Instalasi } \\
\text { berhasil }\end{array}$ & $\begin{array}{l}\text { Berjalan baik tanpa ada } \\
\text { pesan kesalahan (error) }\end{array}$ \\
\hline 2. & $\begin{array}{l}\text { Emulator } \\
\text { Android } \\
\text { (Nox) }\end{array}$ & $\begin{array}{c}4.4 .4 \\
(\text { Kitkat) }\end{array}$ & $\begin{array}{l}\text { Instalasi } \\
\text { berhasil }\end{array}$ & $\begin{array}{l}\text { Berjalan baik tanpa ada } \\
\text { pesan kesalahan (error) }\end{array}$ \\
\hline 3. & OPPO A37F & $\begin{array}{c}5.1 .1 \\
(\text { Lollipop) }\end{array}$ & $\begin{array}{l}\text { Instalasi } \\
\text { berhasil }\end{array}$ & $\begin{array}{l}\text { Berjalan baik tanpa ada } \\
\text { pesan kesalahan (error) }\end{array}$ \\
\hline 4. & OPPO A57 & $\begin{array}{c}\text { 6.0.1 } \\
\text { (Marshmallow) }\end{array}$ & $\begin{array}{l}\text { Instalasi } \\
\text { berhasil }\end{array}$ & $\begin{array}{l}\text { Berjalan baik tanpa ada } \\
\text { pesan kesalahan (error) }\end{array}$ \\
\hline 5 & $\begin{array}{l}\text { Xiaomi } \\
\text { Redmi } 4 X\end{array}$ & $\begin{array}{c}\text { 7.o } \\
\text { (Nougat) }\end{array}$ & $\begin{array}{l}\text { Instalasi } \\
\text { berhasil }\end{array}$ & $\begin{array}{l}\text { Berjalan baik tanpa ada } \\
\text { pesan kesalahan (error) }\end{array}$ \\
\hline
\end{tabular}




\section{SIMPULAN}

Berdasarkan penelitian yang sudah dilakukan dan pengujian perangkat, dapat disimpulkan bahwa penerapan teknologi Augmented Reality dalam pembuatan media pembelajaran Magic Book Pengenalan Profesi dapat berjalan dengan baik diberbagai perangkat dan berbagai macam versi sistem operasi Android. Penerapan teknologi Augmented Reality memicu siswa untuk lebih banyak menggunakan panca indra selama penggunaan aplikasi, membuat proses belajar lebih atraktif dan menyenangkan sehingga penerimaan materi akan lebih optimal karena melibatkan gaya belajar visual, auditori, dan kinestetik. Disertakan juga 2 jenis permainan sebagai hiburan bagi siswa yang bisa juga digunakan sebagai alat ukur penerimaan materi yang didapatkan oleh siswa.

\section{UCAPAN TERIMA KASIH}

Puji syukur penulis panjatkan kepada Allah SWT, karena atas berkat dan rahrnat-Nya, penulis dapat menyelesaikan penelitian dengan judul "Pemanfaatan Augmented Reality Dalam Aplikasi Magic Book Pengenalan Profesi Untuk Pendidikan Anak Usia Dini".

1. Bapak Dr. H.M. Nasrullah Yusuf, S.E., M.B.A. selaku Rektor Universitas Teknokrat Indonesia.

2. Bapak Dr. H. Mahathir Muhammad, S.E., M.M. selaku Dekan Fakultas Teknik dan Ilmu Komputer Universitas Teknokrat Indonesia.

3. Ibu Dyah Ayu Megawaty, M.Kom., selaku Ketua Program Studi S1 Informatika Fakultas Teknik dan Ilmu Komputer Universitas Teknokrat Indonesia.

\section{REFERENSI/DAFTAR PUSTAKA}

Adrian, Q. J. 2019. Game Edukasi Pembelajaran Matematika Untuk Anak SD Kelas 1 Dan 2 Berbasis Android. Jurnal Teknoinfo.

Affan, M., 2015, Perancangan Media Pembelajaran Interaktif 3D Tata Surya Menggunakan Teknologi Augmented Reality Untuk Siswa Kelas 6 Sekolah Dasar Sangira, 1(2), 45-60.

Amin, D., and Govilkar, S., 2015, Comparative Study of Augmented Reality Sdk's, International Journal on Computational Science \& Applications, 5(1), 11-26.

Ardhianto, E., and Hadikurniawati, W., 2012, Augmented Reality Objek 3 Dimensi dengan Perangkat Artoolkit dan Blender, Jurnal Teknologi Informasi DINAMIK, 17(2), 107-117.

Arsyad, Azhar. 2002. Media Pembelajaran. Jakarta: Raja Grafindo.Bagus, I., and Mahendra, M., 2016, Implementasi Augmented Reality (AR) Menggunakan Unity 3D Dan VuporiaSdk, Jurnal Ilmiah ILMU KOMPUTER Universitas Udayana, 9(1), 1-5.

Djam'an Satori. 2007. Profesi Keguruan. Jakarta: Universitas Terbuka Filofteia, M. ,2013, AUGMENTED REALITY STATE OF KNOWLEDGE, USEAND, The USV Annals of Economics and Public Administration, 13(2), 215-227.

Fransiska, E, D., Akhriza, T, M., and Primandari, L, A. 2017. Implementasi Teknologi Augmented Reality Sebagai Media Pembelajaran Informatif Dan Interaktif Untuk Pengenalan Hewan, 651-660.

Gede, I. D., Dhiyatmika, W., Gede, I. K., Putra, D., Made, N., and Marini, I., 2015,Aplikasi Augmented Reality Magic Book Pengenalan Binatang untuk Siswa TK. Lontar Komputer, 6(2), 589-596.

J.Jacobs, R.C.W. Webber-Youngman, E.A. van W., 2016. Potential Augmented Reality Applications in the Mining Industry: Research Gate.

Maulana, A., and Kusuma, W. 2014. Aplikasi Augmented Reality sebagai Media Pembelajaran Tata Surya, Prosiding Seminar Ilmiah Nasional Komputer dan Sistem Intelijen, 53-59.87

Pramana, Y, A., Brata, K, C., and Brata, A, H. 2018. Pembangunan Aplikasi Augmented Reality untuk Pengenalan Benda di Museum Berbasis Android (Studi Kasus : Museum Blambangan Banyuwangi), Jurnal Pengembangan Teknologi Informasi dan Ilmu Komputer, 2(5), 2034-2042.

Rahmanto, Y., Utama, R. Y. 2018. Penerapan Teknologi Web3D Berbasis Android sebagai Media Pembelajaran Gerakan Dasar Silat - Jurnal TAM (Technology Acceptance Model).

Saputra, V., H. Darwis, D., Febrianto, E. 2020. Rancang Bangun Aplikasi Game Matematika Untuk Penyandang Tunagrahita Berbasis Mobile - Jurnal Komputer dan Informatika.

Sudarmilah, E., and Wibowo, P, A. 2016. Aplikasi Augmented Reality Game Edukasi untuk Pengenalan Organ Tubuh Manusia, Jurnal Ilmu Komputer dan Informatika, 2(1), 20-25.

Sugara, E. P. A., Mahmudi, M. A., and Wahyudi, S., 2017, Aplikasi Pengenalan Profesi Pekerjaan bagi Anak Usia Dini Berbasis Augmented Reality, RiauJournal Of Computer Science, 3(2), 89-96 